very trustworthy. The causes of the failure of the ignition system are almost always due to battery and wiring faults; they are very rarely due to the ignition apparatus itself. The contact breaker, coil and ignition switch are generally mounted at different points and thus their action is dependent on the soundness of the wiring between them. Loss of magnetism which used to cause trouble with magnetos is absent in coil systems. Ease in starting up an engine is a prominent feature in coil ignition; at whatever speed the engine is turning, a good spark is always obtained at the plug points. The contact breaker is usually the first component to be examined following an ignition failure, and hence its accessibility and ease of adjustment are of great importance. In this respect, coil ignition has nearly always the advantage. A clear view of magneto contact breakers can rarely be attained without the aid of a mirror. Coil ignition is also greatly superior to the magneto so far as the rapid replacement of faulty parts is concerned.

\section{Scandinavian Museums}

An article by J. A. Sidney Stendall on museums in Scandinavia (Museums J., 38, 397, Nov. 1938) should prove of value to museum curators in Great Britain. The author selects for special description details of exhibition technique. His diagrams of methods of showing specimens, of artificial lighting, and of construction of exhibition cases for straightforward display or for the building up of pictorial dioramas, show how carefully and successfully these aspects have been considered in the museums of Sweden. There are suggestions here the adoption of which would add interest to many museums in Great Britain.

\section{Chromosoma}

THE development of the chromosome theory of heredity during the last twenty years has led to the publication of some thousands of papers devoted to a study which is at once genetics and cytology. These papers have been published partly in the special genetical journals-Genetics, Baur's Zeitschrift, Genetica, Hereditas and the English and Japanese Journals of Genetics-and partly in the special cytological journals-La Cellule, Cytologia and Messrs. Springer's Zeitschrift für Zellforschung und mikroscopische Anatomie. Many also have been published by the older zoological, botanical and general scientific journals. Messrs. Springer have now divided their journal into two parts, which will appear separately this month, marking not inappropriately the centenary of the cell theory. Part A, Allgemeine Zellforschung und mikroscopische Anatomie will continue to deal with the physiological and histological side of cell-study with which the old journal was largely concerned. Part B, under the short title of Chromosoma, will be in effect a new journal. It will deal with the chromosomes in their twin aspects of cell mechanisms and organs of heredity. Dr. Hans Bauer, of the Kaiser Wilhelm-Institut für Biologie in Berlin-Dahlem, is the general editor. He has secured the collaboration of Dr. Lothar Geitler of Vienna,
Dr. T. Caspersson of Stockholm, Dr. A. Müntzing of Lund, Dr. W. v. Möllendorf and Dr. J. Seiler of Zurich, Dr. O. L. Mohr of Oslo, Dr. C. D. Darlington of London, Dr. F. Schrader of New York, and Dr. Th. Dobzhansky of Pasadena. The balance of zoology and botany, chemistry and genetics in this group should ensure a competent discrimination as well as a new point of view in furthering this youngest of the sciences.

\section{Sixth Pacific Science Congress}

ThE sixth Pacific Science Congress will be held in Berkeley, Stanford and San Francisco, California, during July 24-August 12 under the auspices of the National Research Council of Canada, on the invitation of the U.S. National Research Council. The programme is so constituted as to emphasize the discussion of comprehensive scientific topics of general interest to the peoples living within the Pacific basin, and the theme of the Congress will therefore be "the present stage of knowledge of Pacific scientific problems and methods by which that knowledge may be most profitably enlarged". For this reason, the programme is arranged as a series of symposia rather than a collection of independent papers. Forty-two countries have been invited to take part. Further information can be obtained from Dr. R. E. Clausen, Room 205, Hilgard Hall, University of California, Berkeley, California.

\section{Study Meeting on Magnetism}

A sTuDy meeting on magnetism, to be held in Strasbourg during May 21-25, is being organized by the Institute of Intellectual Co-operation in collaboration with the Service Central de la recherche scientifique de France. The following subjects will be discussed : (1) paramagnetism, very low temperatures, relaxation and nuclear magnetism; (2) optics and paramagnetism, low temperatures and moderately low temperatures; (3) ordinary paramagnetism; (4) ferromagnetism, (a) atomic and molecular moments, (b) ferromagnetism and the crystalline network, $\left(b^{\prime}\right)$ interaction and its relationship to thermodynamics, (c) Curie points, $(d)$ gyromagnetic phenomena. A number of papers have already been arranged, and it is expected that about thirty eminent authorities on the subject will attend the meeting. The papers and a report of the discussions will be published in the fifth volume of the "Scientific Collections" of the Institute. Further information can be obtained from the International Institute of Intellectual Co-operation, 2 Rue de Montpensier, Paris, $\mathrm{I}^{\mathrm{er}}$.

\section{Physics in the Textile Industries}

THE annual general meeting of the Manchester and District Branch of the Institute of Physics is to be held in the Physics Department of the University of Manchester at 7.30 p.m. on Friday, March 17. Immediately after the conclusion of the business of the meeting, Dr. F. C. Toy, chairman of the Branch, will speak on "The Physicist in the Textile Industries", and will attempt to give some idea of the vast scope in textile research for the employment of theoretical 
and applied physics, and for the application of physical methods. In view of the Institute of Physics forthcoming Conference on Textile Physics it may be expected that Dr. Toy's lecture will be of special interest to members of the Institute, and to others connected with the textile industries.

\section{Conference on Industrial Physics}

TнE third Conference on Industrial Physics is being arranged by the Institute of Physics to take place in Leeds during March 23-25 under the presidency of Prof. R. Whiddington. The subject of the Conference is to be "Physics in the Textile Industries". An exhibition of instruments, apparatus and books cognate to this subject is being arranged and will be held in the Physies Laboratories of the University of Ieeds. A section of the Exhibition, intended to be of special interest to non-technical persons, will be devoted to popular applications of physics in the textile industries. Addresses will be given by the president of the Institute of Physics, Dr. C. C. Paterson, on "Colour and Colour Rendering" and by Dr. C. G. Darwin, director of the National Physical Laboratory, on "Heat Effects in Fibres and other Systems". In addition, the following lectures, to be followed by discussions, have been arranged: "The Physics of Humidity" by Prof. R. Whiddington; "Industrial Humidity Control and Measurement" by Dr. Ezer Griffiths ; "The Contribution of Physics to the Development of Industrial Process Control" by Dr. M. C. Marsh; and "Automatic Regulators for the Textile Industries" by Mr. D. Harrison. Visits to local works and research laboratories will be included in the programme, and a Conference dinner is being arranged. There will be no Conference fee, and membership is open to all interested. Further particulars can be obtained from the Secretary, Institute of Physics, 1 Lowther Gardens, Exhibition Road, London, S.W.7.

\section{Announcements}

THE following awards have recently been made by the Royal Academy of Belgium : Charles Lemaire prize to E. Franchimont; François Deruyts prizes to P. Burniat and F. Rozet; Léo Errera prize to A. Dalcq; Joseph Schepkens prize to R. Steysert; Adolphe Wetrems prize (natural sciences) to C. Stevens ; Albert Brachet prize to L. Sven Horstadius. The Paul Fourmarier prize to L. Cayeux. Prof. H. N. Russell, of Princeton, and Prof. A. Pictet, of Geneva, have been elected associates of the section of mathematical and physical sciences of the Academy.

Costantino Gorini has been elected correspondant for the Section of Rural Economy of the Paris Academy of Sciences in succession to the late $\mathrm{L}$. Ravaz.

THE following awards have been made by the Council of the Royal Aeronautical Society. Silver Medal: Major R. H. Mayo, for his work leading to an advancement in aeronautical design; Taylor Gold Medal : Squadron Leader H. P. Fraser, for his paper on "High Wing Loading and Some of Its
Problems from the Pilot's Point of View" ; Wakefield Gold Medal: Mr. Leslie L. Irvin, for his work on parachute design, which has led towards safety in flying; Busk Memorial Prize: Squadron Leader G. M. Buxton, for his paper on "The Development of Sailplanes", and to Mr. H. F. Vessey, for his paper on "Effect of Wing Loading on the Design of Modern Aircraft with Particular Regard to Take-off Problems"; Pilcher Memorial Prize: Mr. H. E. H. Rochefort, for his paper on "The Theory and Practice of Stressed Skin Construction for Aeroplanes"; Usborne Memorial Prize: Mr. P. H. Rayner, for his paper on "Notes on Aero Engine Research".

The following appointments and promotions in the Colonial Service have recently been made: R. K. Tremlett, agricultural officer, Uganda ; J. N. See, veterinary officer, Leeward Islands; W. M. Rogers, tobaceo officer, Agricultural Department, Ceylon; O.J. Voelcker, senior botanist, Agricultural Department, Nigeria; N. R. McHardy (senior inspector of plant diseases), land settlement officer, Jamaica.

The Leipzig Fair will be held on March 5-13. The Samples Fair will be open during March 5-10; but the Great Engineering and Building Fair will be open for the whole time. Further information can be obtained from the London office of the Leipzig Fair, 426-9 First Avenue House, 45 High Holborn, London, W.C.1.

The Federation of Medical Societies of North Africa will hold its annual congress -on April 3-5 at Oran under the presidency of Dr. Jasseron. The subject for discussion will be brucella infections. Further information can be obtained from the general secretary, Dr. René Solal, 16 Boulevard Maréchal Joffre, Oran, Algeria.

The Royal Statistical Society is offering the Frances Wood Memorial Prize, value $£ 30$, for competition in 1939. The Prize is offered for the best investigation, on statistical lines, of any problem affecting the economic or social conditions of the people. Further information can be obtained from the Honorary Secretaries of the Royal Statistical Society, 4 Portugal Street, W.C.2.

WE are asked to state that all reprints of papers of the late Prof. George Barger have been placed in the Department of Chemistry, The University, Glasgow, and copies can be obtained from there on application to the Secretary of that Department.

THE Proceedings of the Linnean Society, Part 4, published on December 30, contain, together with the address of the president, Dr. J. Ramsbottom, ab. stracts of the papers delivered by invitation at the two symposia held by the Society as part of the 150th anniversary celebrations, upon the subjects of "The Concept of Species from the Time of Linnæus to the Present Day" and "Geographical Isolation as a Factor in Species Formation" (NATURE, 141, 998 ; 1938). 